\title{
MODEL PENDIDIKAN KARAKTER QUR'ANI DI RAUDHATUL ATHFAL LABSCHOOL IIQ JAKARTA
}

\author{
FAFIKA HIKMATUL MAULA \\ Institut PTIQ Jakarta. \\ sayyedahmaula@gmail.com
}

\begin{abstract}
ABSTRAK
Karakter adalah kualitas kepribadian yang meliputi akhlak dan moral yang dapat dibentuk oleh pembawaan dari lahir, keluarga, dan lingkungan tempat tumbuh berkembang serta menjadi ciri khusus yang membedakan dengan orang lain. Kualitas pribadi seseorang akan dibentuk atas dasar nilai-nilai karakter yang dilakukannya. Karakter merupakan pengembangan dari nilai-nilai karakter sebagai landasan untuk berperilaku dalam masyarakat. Setiap manusia memiliki potensi yang harus dibimbing dan dikembangkan. Dalam hal ini dunia pendidikan selama ini diharapkan mampu menjadi tumpuan untuk memfasilitasi hal tersebut. Namun yang terjadi justru banyak faktor yang menyebabkan gagalnya pendidikan yakni di antaranya faktor lingkungan, kurangnya perhatian orang tua, model pendidikan, metode yang kurang tepat, materi yang tidak sesuai, dan lain-lain. Atas dasar itu, melalui model pendidikan karakter melalui pengembangan karakter Qur'ani diharapkan mampu menjawab tantangan dari pengembangan nilai-nilai karakter yang ada.
\end{abstract}

Kata Kunci : Karakter, Model Pendidikan, Karakter Qur'ani.

\begin{abstract}
Character is a quality of personality that involves akhlaq and moral. It can grow naturally as people were born, and it also can be improved among family or community, which ended up being a special characteristic that differs somebody to another. The quality of someone's personality is formed by doing basic values of character. Character is a development of character values as a base to act and work together in society. Every person has a potency that should be trained and improved. In this case, education is much epected as a main support system. However, in reality, there are many problems that cause failure in education, such as society, lack of parents' caring, models of education, wrong methods, irrelevant materials, etc. Therefore, choosing Qur'anic character education is expected to solve the problems of people's character values improvement nowadays.
\end{abstract}

Keywords : Characters, Model of Education, Qur'anic Character 


\section{A. PENDAHULUAN}

Pendidikan merupakan media paling sistematis dan efektif untuk memperkuat kecerdasan dan kepribadian seseorang. Masyarakat masih percaya akan lembaga pendidikan untuk mencetak pribadi yang memiliki karakter mulia. Meski demikian, masih banyak agenda perbaikan dalam sistem pendidikan kita, dalam kaitannya dengan membangun karakter bangsa (character building). Dan salah satu fungsi pendidikan adalah membentuk watak dan karakter bangsa serta mengembangkan kemampuan yang dimiliki setiap warganya dalam rangka mencerdasakan anak bangsa. Membangun karakter bukanlah tugas yang mudah, maka diperlukan dukungan dari berbagai pihak, mulai dari lingkungan terkecil, yakni keluarga, lingkungan sekolah, masyarakat dan pemerintah.

Di Indonesia, pendidikan karakter bukanlah hal yang baru dalam dunia pendidikan. Yang mana pendidikan karakter merupakan kajian ilmu yang rasional dan aktual karena membahas tentang tingkah laku manusia yang tidak lekang oleh perubahan zaman. Pendidikan karakter merupakan sebuah istilah yang semakin hari semakin mendapatkan pengakuan dari masyarakat Indonesia saat ini. Banyak yang menyebut bahwa pendidikan telah gagal membangun karakter. Banyak lulusan sekolah yang pandai dalam menjawab soal ujian dan bahkan cerdas, namun mentalnya lemah dan penakut, serta perilakunya kurang terpuji. Terlebih dengan dirasakannya berbagai ketimpangan hasil pendidikan dilihat dari perilaku lulusan pendidikan formal saat ini, semisal tawuran, pembunuhan, korupsi, narkoba, perampokan, dan lain sebagainya. ${ }^{1}$

Saat ini, karakter anak bangsa seringkali dipertanyakan oleh masyarakat. Mereka menuntut pihak sekolah dan pemerintah agar melakukan hal yang terbaik untuk membangun karakter generasi penerus bangsa. Pendidikan karakter merupakan kunci yang sangat penting dalam membentuk kepribadian anak agar menjadi individu yang berkarakter. Seperti anak bisa membuat keputusan dan bertanggungjawab atas apa yang dilakukannya. Banyak faktor yang menjadi penyebab ketidak berhasilan pendidikan, di antaranya: soal kebijakan pemerintah mengenai system pendidikan, kurikulum pendidikan, anggaran pendidikan, kepribadian guru, metode pengajaran yang kurang tepat, peran orang tua yang kurang maksimal, lingkungan belajar yang kurang kondusif, dan model pembelajaran yang kurang tepat.

Sebagai solusi pemerintah mencoba menganjurkan agar sekolah-sekolah menggunakan model pendidikan karakter, model pendidikan konvensional, atau model pendidikan kinestik dipandang sudah tidak cukup mampu untuk menghalau arus deras dampak dari globalisasi. Dan istilah pendidikan karakter sendiri masih jarang didefinisikan oleh banyak kalangan. Kajian secara teoritis terhadap pendidikan karakter, bahkan salah-salah dapat menyebabkan salah tafsir tentang

1 Saihu, "Pendidikan Karakter Berbasis Kearifan Lokal (Studi Di Jembrana Bali)", Edukasi Islami: Jurnal Pendidikan Islam, Vol: 08, No: 01 (2019): 69-90. 
makna pendidikan karakter. Menurut Ratna Megawati yang dikutip oleh Dharma Kesuma dkk, arti "pendidikan karakter merupakan sebuah usaha untuk mendidik anak-anak agar dapat mengambil keputusan dengan bijak dan mempraktikkannya dalam kehidupan sehari-hari, sehingga mereka dapat memberikan kontribusi yang positif kepada lingkungannya". ${ }^{2}$ Menurut pengertian lain pendidikan karakter adalah "upaya sadar dan sungguh-sungguh dari seorang guru untuk mengajarkan nilai-nilai kepada siswanya". ${ }^{3}$ Dalam pengertian sederhana pendidikan karakter diartikan sebuah hal positif apa saja yang dilakukan guru dan berpengaruh kepada karakter atau kebiasaan siswa yang diajarnya.

Wacana pendidikan karakter mulai ramai dibicarakan kembali pada dua dekade belakangan ini. Salah satu tokoh yang kerap disebut adalah Thomas Lisckona melalui karyanya, The Return of Character Education (1993), yang menyadarkan dunia pendidikan di Amerika tentang perlunya pendidikan karakter untuk mencapai cita-cita pendidikan. Menurutnya, program pendidikan yang bertumpu pada pembentukan karakter ini berangkat dari keprihatinan atas kondisi moral masyarakat Amerika. Pembentukan karakter ini didasarkan pada kebutuhan untuk menciptakan komunitas yang memiliki moral kemanusiaan, disiplin moral, demokratis, mengutamakan kerjasama dan penyelesaian masalah, dan mendorong agar nilai-nilai itu dipraktikkan di luar kelas. Dalam konteks Indonesia, character building telah dikembangkan sejak negeri ini berdiri, di mana presiden RI pertama Ir. Soekarno mengemukakan gagasan tentang pentingnya pembentukan karakter bangsa. Ketika itu, nilai-nilai yang diutamakan adalah penghargaan atas kemerdekaan, kedaulatan, dan kepercayaan pada kekuatan sendiri atau berdikari. Mengingat pembentukan karakter bersifat konstektual, maka ia bisa berubah sesuai maksud dan tujuannya, dengan berbasis selalu pada nilai-nilai (values). ${ }^{4}$

Membangun karakter atau akhlak mulia, tidak cukup hanya dilakukan saat belajar di dalam kelas saja, namun yang lebih penting membentuk moral, karakter atau budi pekerti di lingkungan masyarakat. Budi pekerti menunjukkan etika yang baik dan sangat penting bagi diri seseorang agar dirinya eksis pada waktu berhubungan dengan orang lain. Dan akhlak adalah merupakan nilai-nilai yang khas yang baik, berbuat baik dalam kehidupan yang berdampak positif atau baik, baik bagi dirinya atau lingkungan tempat tinggalnya. Karakter memancar dari olah pikir, olah hati, olah raga, olah rasa, individu, kelompok, maupun masyarakat. ${ }^{5}$

${ }^{2}$ Dharma Kesuma. Dkk., Pendidikan Karakter: Kajian Teori dan Praktik Sekolah (Bandung: PT. Remaja Rosdakarya, 2011), 5.

${ }^{3}$ Muchlas Samani, dan Hariyanto, Konsep dan Model Pendidikan Karakter (Bandung: PT. Remaja Rosdakarya, 2011), 43.

${ }^{4}$ Lanny Octavia, dkk., Pendidikan Karakter berbasis Tradisi Pesantren (Jakarta: Rumah Kitab, 2014), 10-11

${ }^{5}$ Maswardi M. Amin, Pendidikan Karakter Anak Bangsa Edisi 2 (Yogyakarta: Calpus, 2015), 3. 
Pendidikan karakter merupakan upaya yang dilakukan dengan melibatkan banyak pihak, baik rumah tangga atau keluarga, sekolah dan lingkungan sekolah, serta masyarakat luas. Oleh karena itu, perlu menyambung kembali hubungan dan educational networks yang mulai terputus tersebut. Tidak akan berhasil selama antar lingkungan pendidikan tidak ada kesinambungan dan keharmonisan. Dengan demikian keluarga atau rumah tangga sebagai lingkungan pembentukan dan pendidikan karakter pertama dan utama harus lebih diberdayakan, hendaklah keluarga mampu menjadi sekolah untuk kasih sayang atau tempat belajar yang penuh cinta kasih sayang. Sedangkan pendidikan karakter melalui sekolah, tidak semata-mata pembelajaran pengetahuan semata, tetapi lebih dari itu, yaitu penanaman moral, nilai dan etika, estetika, budi pekerti yang luhur dan lain sebagianya. Lingkungan masyarakat juga sangat mempengaruhi terhadap karakter dan watak seseorang. Lingkungan masyarakat luas sangat mempengaruhi terhadap keberhasilan penanaman nilai-nilai etika, estetika untuk pembentukan karakter. Menurut Quraish Shihab "situasi kemasyarakatan dengan sistem nilai yang dianutnya, mempengaruhi sikap dan cara pandang masyarakat secara keseluruhan". 6

Karakter sering dipandang sebagai cara berfikir dan berperilaku yang menjadi ciri khas tiap individu untuk hidup dan bekerjasama, baik dalam lingkungan keluarga, masyarakat, bangsa dan negara. Menanamkan karakter Qur'ani bagi setiap muslim adalah sebuah kewajiban sebagai jalan menuju ketakwaan kepada Allah Swt.

Karena itu guna membangun sebuah karakter Qur'ani di dalam masyarakat, harus dimulai dengan membangun kebiasaan-kebiasaan baik dari unit terkecil masyarakat, yaitu keluarga inti dan lingkungan terdekat. Karakter Qur'ani adalah tatanan perilaku manusia yang sejalan dengan nilai-nilai moral yang terkandung dalam kitab suci Al-Qur'an. Secara umum karakter moral manusia berhubungan dengan budi pekerti yang mengakar pada diri seseorang. Dalam hal ini membentuk karakter adalah mengaplikasikan nilai-nilai kebaikan dalam bentuk tindakan atau tingkah laku, sehingga orang yang tidak jujur, tamak, dusta, dan sejenisnya dikatakan sebagai orang yang berkarakter buruk. Sebaliknya, orang yang berperilaku sesuai dengan kaidah moral disebut sebagai orang yang berkarakter baik.

Allah Swt. tidak hanya menginginkan kita agar senantiasa membaca AlQur'an, namun lebih dari itu yakni melanjutkan pada proses berfikir dan memahami. Moral karakter Qur'ani menjadikan manusia untuk menjadi pembelajar sepanjang hidup, berkemampuan membaca, memahami, sekaligus menerapkan nilai-nilai kebaikan kitab suci Al-Qur'an ke dalam kehidupan sehari-hari. Terlalu banyak dan sudah sangat jelas beragam ilmu yang dapat digali dari Al-Qur'an

${ }^{6}$ Muhammad Quraish Shihab, Tafsir Al-Misbah: Pesan, Kesan, dan Keserasian Al-Qur'an (Jakarta: Lentera Hati, 2002), 321. 
menyangkut metode pembentukan karakter manusia. Dan pendidikan karakter Qur'ani adalah usaha atau bimbingan yang dilakukan oleh orangtua, guru, atau orang dewasa untuk membangkitkan sifat-sifat kebaikan yang bersumber dari alQur'an dan Sunnah Rasulullah Saw dengan menyeimbangkan antara ilmu, iman, akhlak, dan amal dalam kepribadian anak yang diperuntukkan untuk kemaslahatan kehidupan manusia. ${ }^{7}$

Tujuan pendidikan karakter Qur'ani adalah untuk meningkatkan kualitas diri manusia dalam segala aspek, baik aspek aqidah, ibadah, akhlak, spiritual, sosial, pemikiran baik jasmani maupun rohani secara menyeluruh dan seimbang sehingga dapat menyampaikan seorang hamba kepada tingkat penghambaan diri secara mutlak kepada Allah Swt. ${ }^{8}$ Pendidikan karakter Qur'ani diharapkan dapat meningkatkan dan mensucikan diri manusia serta memperindah kepribadiannya sehingga dapat menjalin hubungan baik dengan Allah Swt dan orang lain bahkan dengan dirinya sendiri dalam meniti tangga penghambaan diri. Setiap kali itu pula keindahan dan kesucian dirinya meningkat. Dan tujuan pendidikan karakter tersebut dapat diwujudkan dalam kehidupan nyata berkat pendidikan yang telah diajarkan secara langsung oleh Rasulullah Saw, sehingga menjadikan para sahabat sebagai suri tauladan yang baik bagi seorang hamba sejati dalam kehidupan seharihari.

\section{B. METODE}

Penelitian pada penulisan ini termasuk dalam jenis penelitian yang menggunakan pendekatan kualitatif. Pendekatan kualitatif digunakan apabila data yang hendak dikumpulkan adalah data kualitatif, yaitu data yang disajikan dalam bentuk kata-kata atau kalimat. Penelitian kualitatif sangat mengutamakan kualitas data, sehingga dalam penelitian tidak digunakan analisis statistika. ${ }^{9}$ Dan penelitian ini merupakan penelitian lapangan (Field study research) yang bermaksud mempelajari secara intensif tentang latar belakang keadaan sekarang dan interaksi sosial, individu, kelompok, lembaga dan masyarakat. Dalam hal ini adalah yang ada hubungannya dengan lembaga pendidikan. Peneliti akan meneliti pada RA Labschool IIQ Jakarta. Jenis penelitian ini adalah penelitian kualitatif dengan metode deskriptif analisi, yaitu berusaha memaparkan secara sistematis materi pembahasan yang berasal dari berbagai sumber untuk kemudian diamati dengan cermat guna memperoleh hasil sebagai kesimpulan. Dengan ini, penelitian deskriptif mengambil masalah atau memusatkan perhatian pada masalah-masalah aktual sebagaimana

7 Ade Jamarudin, “Membangun Pendidikan Karakter Bangsa Menurut Al-Qur'an” https://uin-suska.ac.id/2019/03/25/membangun-pendidikan-karakter-bangsa-menurut-all-quran/.html. Diakses Pada 12 September 2019.

8 Ibrahim Eldeeb, Be A Living Qur'an: Petunjuk Praktis Penerapan Ayat-ayat Al-Qur'an dalam Kehidupan Sehari-hari (Ciputat: Lentera Hati, 2009), 142.

${ }^{9}$ Sulistiyo-Basuki, Metode Penelitian (Jakarta: Penaku, 2010), 29. 
adanya saat penelitian dilaksanakan. Penelitian ini mengkaji bentuk, aktifitas, karakteristik, perihal hubungan, kesamaan, dan perbedaan dengan fenomena lain, atau objek tertentu kemudian dianalisis secara lebih kritis. ${ }^{10}$

\section{HASIL DAN PEMBAHASAN}

\section{Implementasi Model Pendidikan Karakter Qur'ani}

Pendidikan karakter merupakan sebuah proses yang terencana untuk membentuk, mengarahkan, dan membimbing perilaku peserta didik dalam kehidupan sehari-hari yang sesuai dengan norma yang berlaku di masyarakat. Dan di dalam norma tersebut terdapat sistem nilai, yang mana jika kita tarik dalam konteks Islam, maka sistem nilai tersebut adalah ajaran al-Qur'an dan Hadist. Pola sikap dan tindakan yang dihasilkan dari sistem nilai mencakup hubungan dengan Allah Swt, sesama manusia, dan dengan alam. ${ }^{11}$ Dengan demikian, ruang lingkup pendidikan karakter dalam al-Qur'an mencakup hal-hal berikut:

a. Hubungan manusia dengan Allah Swt

Dalam ruang lingkup ini, nilai-nilai pendidikan karakter yang harus ditanamkan kepada peserta didik antara lain sebagai berikut:

1) Takwa: makna asal dari takwa adalah pemeliharaan diri. Secara istilah, takwa adalah memelihara diri dari siksaan Allah Swt dengan mengikuti segala perintah-Nya dan menjauhi larangan-Nya.

2) Cinta: hal ini merupakan kesadaran diri, perasaan jiwa, dan dorongan yang menyebabkan seorang terpaut hatinya kepada apa yang dicintainya dengan penuh semangat dan kasih sayang. ${ }^{12}$

3) Ikhlas: berbuat semata-mata mengharapkan ridha Allah Swt, dalam bahasa yang populer di masyarakat Indonesia ikhlas merupakan perbuatan tanpa pamrih.

4) Khauf dan Raja': takut dan berharap adalah sepasang sikap batin yang harus dimiliki secara seimbang oleh setiap Muslim, bila salah satunya mendominasi maka akan melahirkan pribadi yang tidak seimbang. ${ }^{13}$

5) Tawakkal: yakni membebaskan diri dari segala ketergantungan kepada selain Allah Swt, dan menyerahkan segala sesuatunya kepada-Nya. Seorang muslim hanya boleh bertawakkal kepada Allah Swt semata-mata sebagaimana firman Allah dalam QS. Hud (11): $123 .{ }^{14}$

10 Nana Syaid Sukmadinata, Metode Penelitian Pendidikan (Bandung: Remaja Rosdakarya: 2005), 72 .

${ }^{11}$ Muslim Nurdin, dkk., Moral dan Kognisi Islam: Buku Teks Agama Islam untuk Perguruan Tinggi Umum (Bandung: Alfabeta, 2001), 205.

${ }^{12}$ Novan Ardy Wiyani, Pendidikan Karakter berbasis Total Quality Manajemen (Jakarta: Ar-Ruzz Media), 77-78.

${ }^{13}$ Yunahar Ilyas, Kuliah Akhlaq (Yogyakarta: LPPI UMY, 2011), 37.

${ }^{14}$ Yunahar Ilyas, Kuliah Akhlaq, 44. 
6) Syukur: berarti memuji pemberi nikmat atas kebaikan yang telah dilakukannya. Syukurnya seorang muslim berkisar atas tiga hal yakni hati, lisan, dan anggota badan. Hati untuk ma'rifah dan mahabbah, lisan untuk memuja dan menyebut nama Allah Swt, serta anggota badan untuk menggunakan nikmat yang diterimanya sebagai sarana untuk menjalankan ketaatan kepada Allah Swt dan menahan diri dari maksiat kepada-Nya.

7) Muraqabah: berasal dari kata raqaba yang berarti menjaga, mengawal, menanti, dan mengamati, semua pengertian di atas dapat disimpulkan dalam satu kata yakni pengawasan. ${ }^{15}$

8) Taubat: orang yang bertaubat kepada Allah Swt adalah orang yang kembali dari sesuatu menuju sesuatu; kembali dari sifat yang tercela menuju sifat yang terpuji. Kesalahan atau kemaksiatan yang melanggar ketentuan syariat Islam, hal ini sesuai dengan QS Al-Tahrim (66):8.

b. Hubungan manusia dengan sesama ${ }^{16}$

Dalam ruang lingkup ini, nilai-nilai pendidikan karakter yang harus ditanamkan kepada peserta didik antara lain sebagi berikut:

1) Shiddiq: berarti benar atau jujur, lawan dari dusta atau bohong (al-kadzib). Seorang muslim diwajibkan untuk selalu berada dalam keadaan benar lahir dan batin. Benar dari hati, benar dalam perkataan, dan benar dalam perbuatan.

2) Amanah: artinya dapat dipercaya, seakar dengan kata iman karena amanah memang lahir dari kekuatan iman. Semakin tipis keimanan seseorang, semakin pudar juga sifat amanah pada dirinya.

3) Istiqamah: artinya tegak lurus, yakni teguh dalam pendirian dan senantiasa konsisten. Dalam ilmu akhlak, istiqamah adalah sikap teguh dalam mempertahankan keimanan dan keislaman sekalipun menghadapi berbagai macam tantangan dan godaan. Perintah untuk beristiqamah ada dalam QS. Hud (11):12, Asy-Syura (42):15.

4) Iffah:menjauhkan diri dari hal-hal yang tidak baik dan juga dapat berarti kesucian tubuh. Secara estimologis iffah adalah memelihara kehormatan diri dari segala hal yang akan merendahkan, merusak, dan menjatuhkan.

5) Mujahadah: berasal dari kata jahada-yujahidu-mujahadah-jihad yang berarti mencurahkan segala kemampuan. Dalam ilmu akhlak, mujahadah diartikan sebagai upaya mencurahkan segala kemampuan untuk melepaskan diri dari segala hal yang menghambat pendekatan diri kepada Allah Swt, baik hambatan yang bersifat internal maupun eksternal.

\footnotetext{
${ }^{15}$ Novan Ardy Wiyani, Pendidikan Karakter berbasis Total Quality Manajemen, 81-82.

16 Yunahar Ilyas, Kuliah Akhlaq, 103-107.
} 
6) Syaja'ah: yakni berani, tetapi bukan berani dalam arti siap menantang siapa saja tanpa memedulikan apakah dia berada di pihak yang benar atau salah dan juga bukan berani memperturutkan hawa nafsu. Berani yang dimaksud adalah berani yang berlandaskan kebenaran dan dilakukan dengan penuh pertimbangan. ${ }^{17}$

7) Tawadlu': berarti rendah hati, lawan dari kata sombong atau takabur. Orang yang rendah hati tidak memandang dirinya lebih dari orang lain, sementara orang yang sombong menghargai dirinya secara berlebihan.

8) Malu (al-haya'): sifat atau perasaan yang menimbulkan keengganan melakukan sesuatu yang rendah atau tidak baik. Orang yang memiliki rasa malu jika melakukan sesuatu yang tidak patut, rendah, atau tidak baik dia akan terlihat gugup. Sebaliknya, orang yang tidak mempunyai rasa malu akan melakukannya dengan tenang tanpa ada rasa gugup sedikitpun.

9) Sabar (al-shabr): menahan atau mengekang diri, secara terminologis sabar berarti menahan diri dari segala seuatu yang tidak disukai karena mengharap ridha Allah Swt.

10) Pemaaf: adalah sikap suka memberi maaf terhadap kesalahan orang lain tanpa ada sedikitpun rasa benci dan keinginan untuk membalas.

11) Adil: adil diartikan sebagai sikap berpihak pada yang benar, berpegang teguh pada kebenaran, sepatutnya, dan tidak sewenang-wenang. ${ }^{18}$

c. Hubungan manusia dengan alam

Dalam ruang lingkup ini, nilai-nilai pendidikan karakter yang harus ditanamkan kepada peserta didik antara lain sebagai berikut: 1) Menjaga kebersihan; 2) Tidak menyakiti binatang, hal ini seperti yang terdapat dalam QS. Al-Isra' (17):44; 3) Merawat tumbuhan: eksistensi tumbuhan diakui oleh al-Qur'an dalam beberapa ayat, salah satunya adalah QS Al-An'am (6):99. Dalam ayat tersebut Allah Swt menyuruh kepada manusia untuk mengobservasi perkembangan tumbuhan yang berbuah hingga buahnya matang; 4) Menjaga kelestarian alam: lestari atau tidaknya alam tergantung pada manusianya, dijelaskan dalam QS Ar-Rum (30):41 bahwa semua bentuk kelestarian alam adalah kewajiban manusia untuk senantiasa menjaga dan merawatnya. ${ }^{19}$

Penerapan pendidikan karakter dilihat melalui bentuk integrasi, yaitu integrasi ke dalam mata pelajaran, integrasi melalui pembelajaran tematik, integrasi melalui kegiatan ekstrakurikuler, integrasi antara program pendidikan sekolah, keluarga, dan masyarakat.

17 Novan Ardy Wiyani, Pendidikan Karakter berbasis Total Quality Manajemen, 87.

18 Alwi Hasan, dkk., Kamus Besar BahasaIndonesia (Jakarta: Balai Pustaka, 2002), 8.

${ }^{19}$ Muslim Nurdin, dkk., Moral dan Kognisi Islam: Buku Teks Agama Islam untuk Perguruan Tinggi Umum (Bandung: Alfabeta, 2001), 174. 
a. Integrasi ke dalam mata pelajaran

Pelaksanaan pendidikan karakter dilakukan secara terintegrasi dalam penyusunan silabus dan indikator yang merujuk pada standar kompetensi dan kompetensi dasar. ${ }^{20}$ Kegiatan pembelajaran dalam kerangka pengembangan karakter peserta didik dapat menggunakan pendekatan konstektual sebagai konsep belajar dan mengajar yang membantu guru dan peserta didik mengaitkan antara materi yang diajarkan dengan situasi dunia nyata, sehingga peserta didik mampu untuk membuat hubungan antara pengetahuan yang dimilikinya dengan penerapannya dalam kehidupan mereka. Dengan begitu, melalui pembelajaran konstektual peserta didik lebih memiliki hasil yang komprehensif tidak hanya pada tataran kognitif (olah pikir), tetapi pada tataran afektif (olah hati, rasa, dan karsa) serta psikomotorik (olah raga).

Moral knowing/Learning to know. Merupakan langkah pertama dalam pendidikan karakter. $^{21}$ Tujuan dioreientasikan pada penguasaan pengetahuan tentang nilai-nilai. Siswa harus mampu membedakan nilai-nilai akhlak mulia dan akhlak tercela serta nilai-nilai universal, memahami secara logis dan rasional (bukan secara dogmatis dan doktiner) pentingnya akhlak mulia dan bahaya akhlak tercela dalam kehidupan, mengenal sosok nabi Muhammad Saw sebagai figur teladan mulia melalui hadits-hadits dan sunnahnya. ${ }^{22}$

b. Integrasi ke dalam pembelajaran tematis

Pembelajaran tematis adalah pendekatan dalam pembelajaran yang secara sengaja mengaitkan atau memadukan beberapa kompetensi dasar dan indikator dari beberapa mata pelajaran untuk dikemas dalam suatu kesatuan. ${ }^{23}$ Pembelajaran tematis memiliki ciri-ciri: berpusat pada peserta didik, memberikan pengalaman langsung, menyajikan konsep dari berbagai mata pelajaran dalam suatu tema, bersikap fleksibel, hasil pembelajaran dapat berkembang sesuai dengan minat dan kebutuhan peserta didik.

c. Integrasi melalui pembiasaan

Pembiasaan budaya sekolah dan pusat kegiatan belajar dilakukan melalui kegiatan pengembangan diri, yaitu: 1) Kegiatan rutin, kegiatan yang dilakukan peserta didik secara terus menerus dan konsisten setiap saat;24 2) Kegiatan spontan,

${ }^{20}$ Agus Zaenul Fitri, Pendidikan Karakter Berbasis Nilai dan Etika di Sekolah (Yogyakarta: ArRuzz Media, 2012), 47.

${ }^{21}$ Abdulloh Hamid, Pendidikan Karakter Berbasis Pesantren: Pelajar dan Santri dalam Era IT dan Cyber Culture (Surabaya: Imtiyaz, 2017), 25.

${ }^{22}$ Abdul Majid dan Dian Andayani, Pendidikan Karakter Perspektif Islam (Bandung: PT. Remaja Rosdakarya, 2011), 112.

${ }^{23}$ Agus Zaenul Fitri, Pendidikan Karakter Berbasis Nilai dan Etika di Sekolah, 49.

${ }^{24}$ Masnur Muslich, Pendidikan Karakter Menjawab Tantangan Krisis Multidimensional, 176. 
kegiatan yang dilakukan peserta didik secara spontan pada saat itu juga; 3) Keteladanan, merupakan sikap dan perilaku guru dan tenaga kependidikan dan peserta didik dalam memberikan contoh melalui tindakan-tindakan yang baik sehingga diharapkan mampu menjadi panutan bagi peserta didik lainnya; ${ }^{25} 4$ ) Pengkondisian, yaitu menciptakan kondisi yang mendukung keterlaksanaan pendidikan karakter. ${ }^{26}$

Moral doing/leraning to do, inilah yang menjadi puncak keberhasilan mata pelajaran pendidikan agama Islam, siswa mempraktikkan nilai-nilai akhlak mulia itu dalam perilakunya sehari-hari. Moral doing merupakan perbuatan atau tindakan moral yang merupakan hasil dari dua komponen karakter lainnya. Untuk memahami sesuatu mendorong seseorang melakukan perbuatan yang baik, harus dilihat tiga aspek lain dari karakter. Ketiga aspek tersebut adalah kompetensi (competence), keinginan (will), dan kebiasaan (habit). ${ }^{27}$

d. Integrasi melalui kegiatan ekstrakurikuler

Kegiatan ekstrakurikuler dapat berperan dalam pendidikan karakter yang dilakukan melalui: 1) Pramuka; 2) Palang merah praja; 3) Olahraga; 4) Karyawisata; 5) Outbond.

Moral loving/moral feeling, belajar mencintai dan melayani orang lain. Belajar mencintai dengan cinta tanpa syarat. Tahapan ini dimaksudkan untuk menumbuhkan rasa cinta dan rasa butuh terhadap nilai-nilai akhlak mulia. Dalam tahapan ini yang menjadi sasaran guru adalah dimensi emosional siswa, hati, atau jiwa. Bukan lagi akal, rasio dan logika. Melalui tahapan ini pun siswa diharapkan mampu menilai diri sendiri (muhasabah), semakin tahu kekurangan-kekurangan akan dirinya. ${ }^{28}$ Moral feeling merupakan penguatan aspek emosi peserta didik untuk menjadi manusia berkarakter. Penguatan ini berkaitan dengan bentuk-bentuk sikap yang harus dirasakan oleh peserta didik, yaitu kesadaran terhadap jati diri (conscience), percaya diri (self esteem), kepekaan terhadap penderitaan orang lain (emphaty), cinta kebenaran (loving the good), pengendalian diri (self control), dan kerendahan hati (humility). ${ }^{29}$

Dalam pelaksanaan program pendidikan karakter Qur'ani di RA Labschool IIQ Jakarta dapat dilakukan melalui beberapa tahap dan kegiatan. Berikut penulis paparkan terkait kegiatan yang ada di sekolah.

a. Kegiatan Terprogram

Kegiatan terprogram merupakan kegiatan yang sudah terjadwal yang mana dalam pelaksanaannya terlebih dahulu diawali dengan adanya perencanaan atau program dari guru dalam kegiatan pembelajaran (perencanaan semester, satuan

${ }^{25}$ Masnur Muslich, Pendidikan Karakter Menjawab Tantangan Krisis Multidimensional, 17

${ }_{26}$ Muchlas Samani dan Hariyanto, Konsep dan Model Pendidikan Karakter, 147.

27 Jamal Ma'ruf Asmani, Buku Panduan Internalisasi Pendidikan Karakter di Sekolah, 87.

${ }^{28}$ Abdul Majid dan Dian Andayani, Pendidikan Karakter Perspektif Islam, 112.

${ }^{29}$ Jamal Ma'ruf Asmani, Buku Panduan Internalisasi Pendidikan Karakter di Sekolah, 86-87. 
kegiatan mingguan, satuan kegiatan harian) di sekolah. Pelaksanaan pendidikan karakter Qur'ani sendiri pada kegiatan terprogram di RA Labschool IIQ Jakarta tidak hanya terbatas pada kegiatan belajar mengajar di kelas, ekstrakurikuler, dan sebagainya.Melainkan lebih luas dari apa yang mereka pahami melalui pengalaman siswa. Di sekolah ini guru tidak hanya berusaha memenuhi standar kompetensi yang diamanatkan oleh kurikulum nasional, tetapi juga dengan harapan untuk mengarahkan siswa-siswi agar mampu memahami nilai-nilai dari kegiatan belajar mereka di sekolah. Seperti halnya kegiatan field trip,outing class, renang, Jum'at Berbagi, Jum'at bersih, yang memang merupakan bagian dari kegiatan pembelajaran program sekolah yang sejatinya tidak didapatkan hanya di lingkungan sekolah.

\section{b. Kegiatan Sehari-hari atau kegiatan rutin}

Sejatinya pendidikan karakter dapat dilakukan sejak manusia belum dilahirkan, dan karakter dapat dikembangkan sejak bayi dilahirkan atau bahkan lebih awal sebelum itu yakni saat pre-natal. Karena pada tahun pertama kehidupan bayi, telah berkembang kemampuan untuk memahami orang lain. Bayi pada masa tersebut telah dapat mengembangkan rasa empati secara sederhana, kemampuan empati inilah yang menjadi modal pengembangan karakter yang pertama. ${ }^{30}$ Untuk mencapai kematangan moral dan agama anak, penting dikembangkan model pendidikan melalui kegiatan sehari-hari yang biasa dilakukan oleh seluruh siswa yaitu dengan memulai kegiatan belajar di sekolah dimulai pada jam 07.15 wib pagi dengan adanya penyambutan oleh guru-guru di depan kelas, kemudian siswa masuk kelas dengan menyimpan tas, mengganti sepatu dengan sandal, kemudian dilanjutkan kegiatan ekstra kurikuler bagi yang mengikuti kegiatan tersebut sampai pada jam 07.45 wib.

Setelah itu dilanjutkan dengan kegiatan klasikal untuk berbaris bersama dan berdo'a sekaligus pembacaan ikrar, muroja'ah hafalan Al-Qur'an, dan sholat dhuha berjamaah. Kegiatan ini rutin dilaksanakan di sekolah bahkan sudah menjadi ciri khas dan budaya sekolah. Kegiatan Pra-KBM, yaitu kegiatan yang dilaksanakan sebelum memulai kegiatan belajar mengajar di kelas, kegiatan tersebut di antaranya: 1) Pembacaan ikrar dan do'a bersama; 2) Muroja'ah Hafalan Al-Qur'an; 3) Sholat Dhuha Berjamaah

\section{c. Kegiatan Ekstra Kurikuler}

Kegiatan ekstra kurikuler merupakan wadah dan kegiatan bagi siswa guna untuk mengasah dan menyalurkan bakat mereka. Pelaksaan kegiatan ekstra kurikuler bertujuan untuk meningkatkan kemampuan siswa baik kemampuan

${ }^{30}$ Kementerian Pendidikan danKebudayaan Lembaga Penelitian dan Pengabdian kepada Masyarakat Universitas Negeri Yogyakarta, Artikel: Model Pendidikan Karakter Pada Anak Usia Dini Melalui Lagu Dolanan, http://eprints.uny.ac.id/23669/1artikel\%20stranas\%202013.rtf. Diakses pada 13 Desember 2019. 
kognitif, afektif, dan psikomotorik. Selain itu untuk mengembangkan bakat dan minat siswa dalam upaya pembinaan pribadi menuju pembinaan manusia seutuhnya yang positif. Tujuan kegiatan ini memberikan gambaran bagaimana karakter siswa dapat dibangun secara baik. Kegiatan ini juga memberikan fungsi untuk mengembangkan kemampuan dan kreativitas siswa sesuai potensi, bakat, dan minat. Dan ekskul juga memiliki fungsi sosial yakni untuk mengembangkan kemampuan dan rasa tanggung jawab sosial siswa.

Adapun kegiatan ekskul yang selama ini berjalan di RA Labschool IIQ Jakarta di antaranya: 1) Ekskul Mewarnai; 2) Ekskul Murottal; 3) Ekskul Bahasa Inggris dan Arab; 3) Ekskul Menari.

\section{d. MembacaKegiatan Spontan}

Kegiatan ini merupakan kegiatan yang dilakukan justru tidak dengan terprogram, dengan kata lain pembiasaan atau kegiatan yang dilaksanakan secara insidental pada situasi-situasi tertentu (bisa perilaku baik maupun perilaku buruk) dengan cara para siswa diberi kebebasan penuh untuk mengemukakan atau mengekspresikan tanggapan perasaan, penilaian, dan pandangannya terhadap suatu hal yang dijelaskan guru, khususnya nilai karakter.

Siswa diberi kebebasan untuk mengungkapkan pikirannya tanpa ragu dan rasa takut, pembiasaan yang berupa kegiatan spontan untuk mengembangkan karakter di sekolah. seperti halnya: 1) Memberikan hadiah, bisa berupa materi (barang, kebendaan), maupun non materi (seperti pujian, senyuman, ucapan selamat, dan sebagainya) terhadap perilaku yang ditampilkan oleh siswa pada situasi tertentu; 2) Memberikan hukuman atau teguran dan nasihat terhadap peserta didik yang melakukan perilaku kurang baik; 3) Mengucapkan istighfar ketika menemui siswa melakukan kesalahan; 4) Merapikan dan membersihkan barang pribadi seperti botol minum, sajadah, sandal, sepatu, kotak makan, tas, dan sebagainya; 5) Cara meminta tolong yang baik kepada teman dan guru; 6) Cara mengendalikan emosi, dan menghargai orang lain; 7) Berbagi bekal makanan dengan teman; 8) Cara menegur teman ketika melakukan kesalahan, melanggar peraturan, dan lain sebagainya. ${ }^{31}$

\section{e. Keteladanan Guru}

Keteladanan dalam pendidikan merupakan bagian dari sejumlah metode yang paling ampuh dan efektif dalam mempersiapkan dan membentuk anak baik secara moral, spiritual, karakter, dan sosial. Sebab, seorang pendidik merupakan contoh yang ideal dalam pandangan anak, mulai dari penampilan, tingkah laku, tutur kata, akhlak, dan sopan santunnya. Dalam pelaksanaanya, guru-guru di RA Labschool IIQ Jakarta memberikan keteladanan kepada siswa-siswi dengan

${ }^{31}$ Hasil wawancara dengan salah satu guru Farihah Ulinnuha, pada Jum'at 27 September 2019. 
senantiasa membiasakan saling senyum dan sapa, mengucapkan salam tatkala bertemu, senantiasa meminta maaf jika bersalah, dan saling menghargai satu sama lain. Keteladanan guru dalam berbagai aktivitas mendukung keberhasilan penerapan nilai-nilai karakter yang mana secara otomatis akan menjadi teladan dan panutan bagi peserta didiknya. Hal ini sesuai dengan pendapat Nurhasana yang menjelaskan bahwa nilai-nilai yang ditanamkan pada siswa perlu didukung oleh lingkungan yang memberikan teladan. ${ }^{32}$

\section{f. Teguran}

Teguran yang diberikan guru RA Labschool IIQ Jakarta dalam menerapkan kedisiplinan dan karakter siswa salah satunya melalui teguran dengan cara menasehati siswa salah satunya jika ada siswa yang sedang berselisih paham, dimulai dengan mencari akar masalah dengan mencoba mendengarkan klarifikasi dari masing-masing siswa, kemudian mencoba menganalisis bersama masalahnya guna mengasah cara berfikir siswa dalam memecahkan masalah dan mencari solusi, jika sudah ditemukan solusi dan masalahnya, maka guru mendamaikan dan menesahati siswa tersebut. Hal ini sengaja dilakukan dengan harapan siswa dapat memahami kesalahannya dan di kemudian hari mereka tidak akan mengulanginya lagi.

\section{g. Pembinaan dan Pelatihan Guru}

Dalam pelaksanaannya, RA Labschool IIQ Jakarta telah memenuhi prosedur perekrutan sumber daya manusia sebagai tenaga pendidik. Tahapan-tahapan yang dilalui dalam perekrutan sumber daya manusia dalam hal ini tenaga pendidik di sekolah adalah sebagai berikut: perencanaan, tes dan seleksi, penerimaan, pembinaan, pengembangan, dan kepemimpinan yang intensif serta penilaian yang kontinyu.

\section{h. Pengkondisian Lingkungan}

Pengkondisian lingkungan merupakan penyediaan saran fisik, di RA Labschool IIQ Jakarta terdapat beberapa gambar slogan/hadits dan do'a yang ditempel berkaitan dengan pendidikan karakter Qur'ani, tujuannya agar siswa melihatnya setiap hari dan selalu ingat pentingnya nilai karakter yang diterapkan. Begitu juga dengan penyediaan tempat sampah, rak sepatu, rak tas, yang diletakkan di setiap kelas masing-masing. Banyak sekali gambar-gambar bijak untuk ditempelkan dan dijadikan slogan di setiap ruangan kelas, ataupun di lorong sekolah. Tidak hanya itu, pengkondisian lingkungan juga bisa melalui nyanyian lagu-lagu Islami, Hadist dan Mahfudhat, Do'a harian, lagu-lagu sesuai tema pembelajaran, dan sejenisnya.

${ }^{32}$ Hasil wawancara dengan guru bagian Kesiswaan, pada Jum'at, 29 September 2019. 


\section{i. Program Pembiasaan Pendidikan Karakter}

Pembiasaan pendidikan karakter di RA Labschool IIQ Jakarta sangatlah kental, hal ini sejalan dengan dengan visi dan misi yang ada di sekolah tersebut, dan kemudian pembiasaan karakter ditanamkan oleh guru-guru dan para stakholder. Dalam hal ini siswa melakukan berbagai kegiatan di lingkungan sekolah, dari mulai masuk sampai pulang dari sekolah. Peran guru sangatlah berpengaruh pada siswa, karena pembiasaan dan pengawasan dilakukan secara langsung oleh guru-guru sekolah.

\section{KESIMPULAN}

Upaya implementasi model pendidikan karakter Qur'ani di RA Labschool IIQ Jakarta dilakukan dengan berbagai bentuk dan pendekatan sehingga tampak terorganisir dan terlaksana dengan baik.

1. Pelaksaan pembiasaan pendidikan karakter di RA Labschool IIQ Jakarta sudah berjalan cukup baik. Hal ini terbukti dari pelaksanaannya yang dilakukan secara menyeluruh, mulai dari kegiatan siswa sehari-hari maupun kegiatan yang sudah terprogram seperti kegiatan pembelajaran baik di dalam maupun di luar kelas dan pada kegiatan ekstrakurikuler. Pilar-pilar karakter Qur'ani yang dikembangkan di RA Labschool IIQ Jakarta di antaranya: Beriman (religius), Amanah (jujur), Tata (disiplin), Peduli lingkungan dan sosial, Komunikatif, Mandiri, dan Cinta tanah air. Dalam proses pelaksanaan pendidikan karakter di RA Labschool IIQ Jakarta, baik kepala sekolah, guru, serta seluruh stakholder telah berupaya memberikan keteladanan, teguruan, kedisiplinan, nasehat, serta pengarahan kepada siswa dengan harapan agar siswa mampu menyerap dan memahami nilai-nilai karakter yang sekolah tanamkan utamanya untuk perubahan karakter yang lebih baik dalam diri siswa meskipun tanpa siswa sadari.

2. RA Labschool IIQ Jakarta merupakan lembaga yang memiliki potensi cukup bagus untuk mengembangkan pendidikan karakter di lingkungan sekolah, di antaranya: memiliki misi untuk menjadikan sekolah sebagai lingkungan yang berkarakter Qur'ani, tempat yang strategis, memiliki dukungan yang penuh dari orang tua, para guru yang memiliki komitmen untuk menjalankan misi sekolah, serta memiliki kegiatan yang sudah menjadi ciri khas dan budaya sekolah. Adapun hambatan atau kendala yang dialami sekolah dalam melakukan pembiasaan pendidikan karakter di RA Labschool IIQ Jakarta di antaranya: hambatan komunikasi antar guru dan kepada siswa, keterbatasan waktu, hambatan Sumber Daya Manusia (SDM), sarana prasarana, dan peran orang tua dalam pendidikan. Mengingat RA Labschool IIQ Jakarta termasuk sekolah yang memiliki visi dan misi dalam penyelenggaraan pendidikan karakter, karenanya sekolah harus lebih ekstra dalam melaksanakan pendidikan karakter tersebut. 


\section{DAFTAR PUSTAKA}

Amin, Maswardi M. Pendidikan Karakter Anak Bangsa Edisi 2. Yogyakarta: Calpus, 2015.

Eldeeb, Ibrahim. Be A Living Qur'an: Petunjuk Praktis Penerapan Ayat-ayat Al-Qur'an dalam Kehidupan Sehari-hari. Ciputat: Lentera Hati, 2009.

Fitri, Agus Zaenul. Pendidikan Karakter Berbasis Nilai dan Etika di Sekolah. Yogyakarta: Ar-Ruzz Media, 2012.

Hamid, Abdulloh. Pendidikan Karakter Berbasis Pesantren: Pelajar dan Santri dalam Era IT dan Cyber Culture. Surabaya: Imtiyaz, 2017.

Hasan, Alwi. dkk. Kamus Besar BahasaIndonesia. Jakarta: Balai Pustaka, 2002.

Ilyas, Yunahar. Kuliah Akhlaq. Yogyakarta: LPPI UMY, 2011.

Jamarudin, Ade. "Membangun Pendidikan Karakter Bangsa Menurut Al-Qur'an" dalam https://uin-suska.ac.id/2019/03/25/membangun-pendidikan-karakterbangsa-menurut-all-quran/.html.

Kesuma, Dharma. Dkk, Pendidikan Karakter (Kajian Teori dan Praktik Sekolah). Bandung: PT. Remaja Rosdakarya, 2011.

Kementerian Pendidikan danKebudayaan Lembaga Penelitian dan Pengabdian kepada Masyarakat Universitas Negeri Yogyakarta, Artikel: Model Pendidikan Karakter Pada Anak Usia Dini Melalui Lagu Dolanan, http://eprints.uny.ac.id/23669/1artikel\%20stranas\%202013.rtf.

Nurdin, Muslim. dkk. Moral dan Kognisi Islam: Buku Teks Agama Islam untuk Perguruan Tinggi Umum. Bandung: Alfabeta, 2001.

Majid, Abdul, dan Dian Andayani. Pendidikan Karakter Perspektif Islam. Bandung: PT. Remaja Rosdakarya, 2011.

Octavia, Lanny. dkk, Pendidikan Karakter berbasis Tradisi Pesantren. Jakarta: Rumah Kitab, 2014.

Saihu, "Pendidikan Karakter Berbasis Kearifan Lokal (Studi Di Jembrana Bali)", Edukasi Islami: Jurnal Pendidikan Islam, Vol: 08, No: 01 (2019): 69-90.

Samani, Muchlas. dan Hariyanto, Konsep dan Model Pendidikan Karakter. Bandung: PT. Remaja Rosdakarya, 2011.

Shihab, Muhammad Quraish. Tafsir Al-Misbah: Pesan, Kesan, dan Keserasian AlQur'an. Jakarta: Lentera Hati, 2002.

Sukmadinata, Nana Syaodi. Metode Penelitian Pendidikan. Bandung: Remaja Rosdakarya: 2005.

Sulistiyo-Basuki, Metode Penelitian. Jakarta: Penaku, 2010.

Wiyani, Novan Ardy. Pendidikan Karakter berbasis Total Quality Manajemen. Jakarta: Ar-Ruzz Media, 2010. 